\title{
Marketing Extension Needs for Sustainable Extension Practices among Cassava Farmers in Surulere Local Government Area of Oyo State
}

\author{
${ }^{1}$ Ogunleye, K.Y*, ${ }^{2}$ Thomas K. and ${ }^{1}$ Oyebade S. 0 \\ Department of Agricultural Economics and Extension, \\ Ladoke Akintola University of Technology, Ogbomoso, Nigeria \\ ${ }^{2}$ Department of Agricultural Extension and Rural Development, \\ University of Ibadan, Nigeria \\ *E-mail: kennygd2001@yahoo.com, \\ Mobile: +2348058116248
}

\begin{abstract}
The study investigated the marketing extension needs of cassava farmers in Surulere Local Government Area of Oyo State. Multistage sampling technique was used to select one hundred and five respondents from the list of contact farmers obtained from the state Agricultural Development Programme (ADP). Interview schedule was employed to elicit information from the respondents. Data obtained were subjected to descriptive and inferential statistics. Findings from the study revealed $56.2 \%$ of the respondents were within the age range of 31 and 50 years, majority (82.9\%) were married and (65.7\%) had primary education. Majority (70.5\%) had farming as their primary occupation with $77.1 \%$ having farming experience not less than 11 years. A large percent financed their cassava business from their personal savings. Also, substantial respondents (85.7\%) source marketing information from traders. Chi-square analysis revealed that, there was a significant relationship between sex $\left(\chi^{2}=11.667 ; \rho<0.05\right)$, Marital status $\left(\chi^{2}=260.571 ; \rho<0.05\right)$, education $\left(\chi^{2} 50.057 ; \rho<0.05\right)$, primary occupation, $\left(\chi^{2}=17.610, \rho<0.05\right)$, farming experience $\left(\chi^{2}=71.457 ; \rho<0.05\right)$ and marketing extension needs of cassava farmers. However, Age $\left(\chi^{2}=39.33 ; \rho>0.05\right)$, religion $\left(\chi^{2}=2.752 ; \rho>0.05\right)$ and cassava association membership $\left(\chi^{2}=3.438, \rho>0.05\right)$ were not significant. Therefore, agricultural marketing techniques should be incorporated into agricultural extension delivery packages to ensure continuous farming practices and adoption of innovations.
\end{abstract}

Key Words: Marketing, Extension Needs, Cassava Farmers

\section{Introduction}

As agriculture and society develops, marketing becomes more important. In subsistence agriculture, a farmer will mainly be feeding himself and his neighbours but as the population of the cities increases, farmers have the added responsibility of feeding not only the rural market but also the growing distant urban markets (Singh, 2001). In Nigeria, cassava is playing an increasingly important role as a cash crop for urban market (Nweke et al, 2002). Cassava is a year round crop but it is also a highly perishable and bulky produce. The processing of cassava into chips, flour, gari, fufu, alcohol or starch are relevant to a variety of industries, including livestock feeds, textiles and soft drinks and the leaves of cassava are rich in protein and vitamin which are consumed as a preferred green vegetable (Ezedinma, 2007). Several initiatives have been launched to improve the cassava subsector especially in the area of production and this has yielded great results because according to FAO (2009), Nigeria is the largest producer of cassava with 43 million tonnes in 2007. 
In order to have sustainable increase in cassava production the market has to be well developed. Adegeye and Dittoh (1985) defined marketing as concerning all stages of operation which aid the movement of commodities from the farm to the consumer and these include assemblage of goods, storage, transportation, processing, grading and financing of all these activities. It therefore involves all the business activities carried out for the flow of goods and services from the point of initial production until they reach the ultimate consumer. It was further stated that market exists whenever buyers and sellers can be in touch with one another. Buyers and sellers may not necessarily meet face to face before a market exists. The most important factors for the existence of market are that the goods to be sold must exist, there must be buyers and seller and both must agree on a price. For the farmer, the strategic function of a marketing system is to offer him a convenient outlet for his produce (FAO, 1997). Communication plays a vital role in determining the success or failure of commercialization/ marketing of the agricultural produce. The extension system in the rural areas should be re-oriented to meet the challenges in $21 \mathrm{st}$ century due to globalisation (Singh, 2001).

Erahbor and Emokaro, (2007) also stated that marketing sub-sector increasingly tend toward commercialization. Srivastava, (2007) stated that it has become absolute necessity to shift extension focus from production-orientation to market-led extension which results in increasing farm income. Market-led extension help the farmers to minimize the production costs, improve the quality of farm produce, increase the product value and marketability resulting in increase of income to the farmers. Marketing extension are activities which extension workers can carry out to assist farmers with their marketing (FAO, 2002). Therefore, for extension workers to really assist farmers in this regard, it is important to assess from the farmer's perspective in the areas in which assistance is needed for cassava marketing because programs or services can be effective only when they meet real needs and when the target population agrees that it has those needs (Posavac and Carey, 1992) so as to guaranty continuous adoption of extension practices for cassava production. In view of the above, the study was conducted to identify the personal characteristics of the respondents, investigate sources of information available to farmers on cassava marketing and determine the agricultural marketing extension needs of cassava farmers in the study area.

\section{Methodology}

This study was carried out in Surulere Local Government Area (LGA) of Oyo State. The local government headquarter is Iresa- Adu in Ogbomoso. It is located in the south western part of Nigeria. It also shares boundaries with Ifelodun LGA, Orolu LGA) in Kwara State, Oriire Local Government, Ogbomoso North and South LGA. The LGA comprises the following wards, Bayooje, Gambari, Iwofin, Iresa-Apa, Arolu, Iresa-adu, Iregba, Oko, Mayin and Ilajue. Farming and trading are the major primary and secondary occupation of the people in the area. Other income generating activities includes, fishing, teaching, carpentry, craft work, weaving and agricultural processing. The population of study is made up of cassava farmers in Surulere Local Government of Oyo state.

Multi stage sampling technique was used to select respondents used for the study. In the first stage, three wards (Gambari, Iresa-Apa and Iresa-Adu) were purposively selected because of the predominant cassava production in the area. Gambari, Iresa-Apa and Iresa-Adu wards comprises 32, 48 and 32 villages 
respectively. In the second stage, ten percent (3,5 and 3) of the villages in each ward was randomly selected to give a total of 11 villages across the sampled wards. Using the list of registered farmers for the sampled villages obtained from Agricultural Development Project Zonal Office in the state, ten (10) respondents were selected through random sampling technique from each of the sampled villages to give a sample size of 110 . However, only one hundred and five (105) interview guides were analyzable having a response rate of $95.5 \%$.

Data collected through interview schedule were analysed using statistical tools; (i) Frequency distribution and percentage were used to indicate the proportion of responses to certain variables. (ii) Chi-square was used to test relationship between personal characteristics and farmers' marketing extension needs

\section{Results and Discussion \\ Socio-economic characteristics}

From table 1, 66.7 percent of the respondents were males, while the rest $(33.3 \%)$ were females, majority of the respondents $(82.9 \%)$ were married, while only $6.7 \%$ were single. More than half (56.2\%) of the respondents were in the age range $31-50$, few $(29.5 \%)$ were in the age range of $51-60,9.5 \%$ were older than 60 while $4.8 \%$ were younger than 30 . It clearly shows that most of the respondents were in their active and productive age group hence they will maximize the use of extension information. The findings reveal that about $65.7 \%$ of the respondents had primary education, $14.3 \%$ had secondary education. The result thus identifies low literacy level of the respondents in the study area .Majority, (70.5\%) of the respondents were into farming while $(29.5 \%)$ were into trading. The result justified the study area as a predominantly agrarian community.

On years of experience, the table reveals that $77.14 \%$ of the respondents had more than 11years of experience in cassava farming, $17.15 \%$ had between 6 to 10 years of experience and 5years of experience $(5.71 \%)$. It therefore implies that the respondents are well experienced in cassava production. Considering distribution of respondents by kinds of farmers' help groups, about half $(50.5 \%)$ of the respondents were into cooperative society, very few $(9.5 \%)$ respondents belonged to Itesiwaju and Alasopo help groups, while (40\%) did not belong to any group. From this result, barely half of the respondents obtained benefit like credit facilities, advisory services and marketing information to improve production potentials. Also, the table shows that majority $(90.1 \%)$ of the respondents had access to fund for cassava enterprise from personal savings, $39 \%$ sourced for fund by obtaining loans from friends and relatives while more than half $(57.1 \%)$ got fund from the cooperative societies. The implication is that many of the respondent's access fund from personal servings and cooperative society to service their various cassava enterprises.

Table 1: Distribution of respondents by personal characteristics

\begin{tabular}{lll}
\hline Characteristics & Frequency & Percentage \\
\hline
\end{tabular}




\begin{tabular}{|c|c|c|}
\hline \multicolumn{3}{|l|}{ Sex } \\
\hline Male & 70 & 66.7 \\
\hline Female & 35 & 33.3 \\
\hline \multicolumn{3}{|l|}{ Marital status } \\
\hline Single & 7 & 6.7 \\
\hline Married & 87 & 82.9 \\
\hline Widow & 3 & 2.9 \\
\hline Widower & 1 & 1 \\
\hline Separated & 7 & 6.7 \\
\hline \multicolumn{3}{|l|}{ Age } \\
\hline$<30$ & 5 & 4.7 \\
\hline $31-40$ & 21 & 20 \\
\hline $41-50$ & 38 & 36.2 \\
\hline $51-60$ & 31 & 29.6 \\
\hline$\geq 60$ & 10 & 9.5 \\
\hline \multicolumn{3}{|l|}{ Education level } \\
\hline Secondary & 15 & 14.3 \\
\hline Primary & 69 & 65.7 \\
\hline No formal & 21 & 20.0 \\
\hline \multicolumn{3}{|l|}{ Primary Occupation } \\
\hline Farming & 74 & 70.5 \\
\hline \multirow{2}{*}{\multicolumn{3}{|c|}{ Experience }} \\
\hline & & \\
\hline$\leq 5$ & 6 & 5.71 \\
\hline $6-10$ & 18 & 17.15 \\
\hline$\geq 11$ & 81 & 77.14 \\
\hline \multicolumn{3}{|l|}{ Types of Help Group } \\
\hline None & 42 & 40.0 \\
\hline Cooperative & 63 & 60.0 \\
\hline \multicolumn{3}{|l|}{ *Sources of finance } \\
\hline Personal servings & 95 & 90.5 \\
\hline Bank credit & 2 & 1.9 \\
\hline Friends and relatives & 41 & 39.0 \\
\hline Cooperative society & 60 & 57.1 \\
\hline
\end{tabular}

Distribution of Respondents by Sources of Marketing Information

Table 2 indicates that $(61 \%)$ of the respondents had access to marketing information from other farmers, majority (85.7\%) from traders, and $2.9 \%$ obtained from the extension agents. This implies that many of them had access to marketing information through traders and this further shows the reason for extension to assist in the area of marketing so that farmers are encouraged to adopt innovations.

Table 2: Distribution of cassava farmers' sources of marketing information 


\begin{tabular}{lcc}
\hline Marketing Information & *Frequency & Percentage \% \\
\hline Extension agent & 3 & 2.9 \\
Traders & 90 & 85.7 \\
Cooperative & 56 & 53.3 \\
Other farmers & 64 & 61.0 \\
\hline
\end{tabular}

${ }^{\star}$ Multiple Responses

\section{Cassava Farmers' Marketing Needs}

Table 3 shows the various areas of marketing in which farmers need assistance. On market category, all respondents (100\%) need assistance in linking various market channels $(100 \%)$, majority need produce and product market prices $(62.9 \%)$, need assistance on market location for produce and products $(66.7 \%)$ This implies that cassava farmers are in great need of assistance regarding marketing strategy to improve their enterprise and thereby boost their income. Links to credit sources was needed to a large extent by majority (88.6\%) of the respondents. This confirms that credit sources available to farmers were their personal savings and therefore will need more sources of credit to finance their business. Also, great number of the farmers responded they needed credit to purchase equipment (66.7\%), finance processing (72.4\%) and transportation (75.2\%).

On information need of the farmers, the respondents need information to a large extent on available markets $(82.9 \%)$ for their produce or products, Procedure for maximizing profit $(90.5 \%)$ and exporting procedure $(55.2 \%)$. Cassava farmers need, to a large extent, protection from infestation of pest and disease $(60.0 \%)$. Cassava farmers need to a "large extent" training on processing to new products $(81.9 \%)$, training on processing to meet export standard (70.5\%), processing modern equipment $(81.9 \%)$ and training on how to use modern equipment $(82.9 \%)$. Furthermore, cassava farmers to a large extent need good road network $(95.2 \%)$, movement from farm to market $(73.3 \%)$, movement from village to town $(75.2 \%)$, group transportation $(63.8 \%)$, movement from farm to processing site $(72.4 \%)$ and movement from processing site to market $(70.5 \%)$. 
Table 3: Distributions of Respondents According To Cassava Farmers' Marketing Needs

\begin{tabular}{|c|c|c|c|}
\hline Marketing Needs & $\begin{array}{l}\text { Large } \\
\text { Extent }\end{array}$ & Some Extent & Not At All \\
\hline \multicolumn{4}{|l|}{ Marketing } \\
\hline Marketing channels & $105(100.0)$ & -- & -- \\
\hline Produce and product market prices & $66(62.9)$ & $29(27.6)$ & $10(9.8)$ \\
\hline Market location & $70(66.7)$ & $24(22.9)$ & $11(10.5)$ \\
\hline \multicolumn{4}{|l|}{ Credit } \\
\hline Link with credit sources & 93 (88.6) & $12(11.4)$ & -- \\
\hline Credit purchase of equipment & $70(66.7)$ & $21(20.0)$ & 14(13.3) \\
\hline Credit for paying labour & $42(40.0)$ & $47(44.8)$ & $16(15.2)$ \\
\hline To finance processing & $76(72.4)$ & $24(22.9)$ & $5(4.8)$ \\
\hline To finance transportation & $79(75.2)$ & $22(21.0)$ & $4(3.8)$ \\
\hline To purchase equipment & $61(58.1)$ & $29(27.6)$ & $15(14.3)$ \\
\hline \multicolumn{4}{|l|}{ Information } \\
\hline $\begin{array}{l}\text { Introducing farmer to those that can buy } \\
\text { his/her produce }\end{array}$ & $87(82.9)$ & $11(10.5)$ & $7(6.7)$ \\
\hline Where to sell product & $65(61.9)$ & $31(29.5)$ & $9(8.6)$ \\
\hline Market location & $68(64.8)$ & $31(29.5)$ & $6(5.7)$ \\
\hline Exporting procedure & $58(55.2)$ & $38(36.2)$ & $9(8.6)$ \\
\hline Advantage of selling beyond farm gate & $44(41.9)$ & $55(52.4)$ & $6(5.7)$ \\
\hline Procedure for maximizing profit & $95(90.5)$ & $8(9.6)$ & $2(1.9)$ \\
\hline \multicolumn{4}{|l|}{ Storage } \\
\hline \multicolumn{4}{|l|}{ Protection from infestation of pest and } \\
\hline Storage method for cassava & $39(37.1)$ & $51(48.6)$ & $15(14.3)$ \\
\hline $\begin{array}{l}\text { Storage method for products } \\
\text { Processing }\end{array}$ & $40(38.1)$ & $46(43.8)$ & $19(18.1)$ \\
\hline Training on processing to new products & $86(81.9)$ & $15(14.3)$ & $4(3.8)$ \\
\hline $\begin{array}{l}\text { Training on processing to meet export } \\
\text { standard }\end{array}$ & $74(70.5)$ & $26(24.8)$ & $5(4.8)$ \\
\hline Modern processing equipment & $86(81.9)$ & $14(13.3)$ & $5(4.8)$ \\
\hline $\begin{array}{l}\text { Training on skill for operating modern } \\
\text { equipment } \\
\text { Transportation }\end{array}$ & $87(82.9)$ & 14(13.3) & $4(3.8)$ \\
\hline Good road network & $100(95.2)$ & $3(2.9)$ & $2(1.9)$ \\
\hline $\begin{array}{l}\text { Means of transportation from farm to } \\
\text { market } \\
\text { Means of transportation from village to }\end{array}$ & $77(73.3)$ & $19(18.1)$ & $9(8.6)$ \\
\hline town & $79(75.2)$ & $17(16.2)$ & $9(8.6)$ \\
\hline Group transportation for cost reduction & $67(63.8)$ & $33(31.4)$ & $5(4.8)$ \\
\hline $\begin{array}{l}\text { Means transportation from farm to } \\
\text { processing site } \\
\text { Means of transportation from processing }\end{array}$ & $76(72.4)$ & 23(21.9) & $6(5.7)$ \\
\hline site to market & $74(70.5)$ & $24(22.9)$ & $7(6.7)$ \\
\hline
\end{tabular}

${ }^{*}$ Figures in parentheses are percentages

\section{Test of hypothesis}

The Chi-square analysis on table 5 tested relationship between personal characteristics of cassava farmers and farmers' marketing extension needs. Results showed that sex, marital status, education, primary occupation, Cassava farming experience $\left(\chi^{2}=260.71,11.667,50.057,17.610\right.$ and $70.714, P<0.05$ respectively) of 
the respondents were statistically significant. The relationship between marketing extension needs and age of the farmers, Cassava association membership and religion $\left(\chi^{2}=39.333,3.438\right.$ and 2.752 respectively) of the respondents were not significant at $P<0.05$. Sex of the respondents may be significant because majority were male and will need assistance in marketing. Nweke, (2002) corroborates this finding that men worked predominantly on land clearing, ploughing and planting which are production activities. That of marital status may be true because cassava is a good source of income generation for household. Ogundari and Ojo (2007) also validated this finding that cassava serves as a source of income generation for households.

Primary occupation had a significant relationship with marketing extension needs since the primary occupation of most respondents was farming and will therefore need assistance of extension agents in handling increased productivity which comes from the cultivation of improved varieties. Erahbor and Emokaro (2007) stated that improved varieties produce higher yield. Therefore, Cassava farming experience had a significant relationship between marketing extension needs of farmers. This could be because as the farmers gain more experience their productivity increases but because cassava is a crop that does not have long shelf life, farmers will need assistance on marketing.

Table 4: Chi-Square Result Showing Relationship between Personal Characteristics and Farmers' Marketing Extension Needs

\begin{tabular}{|c|c|c|c|c|}
\hline Variable & df & $\chi^{2}$ & $\begin{array}{c}\begin{array}{c}\text { Significant } \\
\text { level }\end{array} \\
\end{array}$ & $\begin{array}{l}\text { Decision on } \\
\text { significance }\end{array}$ \\
\hline$\overline{\operatorname{Sex}}$ & 1 & 11.667 & .001 & Significant \\
\hline Marital status & 4 & 260.71 & .000 & Significant \\
\hline Age & 34 & 39.333 & .243 & Not Significant \\
\hline Education & 2 & 50.057 & .000 & Significant \\
\hline Primary occupation & 1 & 17.610 & .000 & Significant \\
\hline $\begin{array}{l}\text { Cassava farming } \\
\text { experience }\end{array}$ & 29 & 70.714 & .000 & Significant \\
\hline $\begin{array}{l}\text { Cassava association } \\
\text { membership }\end{array}$ & 1 & 3.438 & .064 & Not Significant \\
\hline Religion & 1 & 2.752 & .097 & Not Significant \\
\hline
\end{tabular}

\section{Conclusion}

The conclusion of the finding indicated that, majority of the cassava farmers had low level of education but are well experienced in cassava production. Personal savings was their major source of finance and that the major source of marketing information for the famers were trader hence, the needs for agricultural extension agents to assist in the area of marketing so that farmers will be encouraged to adopt innovations. Cassava farmers are therefore in great need of assistance in marketing of cassava and its products

\section{Recommendations}



suggested.

Based on the findings of the study, the following recommendations are hereby

- Extension agents should take conscious effort to encourage the farmers to form a formidable association that will help the cassava farmers in maintaining a profitable price for their produce.

- Agricultural extension system should train extension agents on issues relating to marketing of agricultural commodities. Agricultural marketing techniques should be incorporated into agricultural extension delivery packages.

- Government and NGOs (Non-governmental organizations) should organize seminar and workshops more frequently in order to educate farmers on information regarding cassava production and marketing.

\section{References}

Adegeye, A. J. and Dittoh, J.S (1985): Essentials of Agricultural Economics. Impact Publishers Nigeria. Ltd, Ibadan, Nigeria. Pp 49,165.

Erahbor P.O. and Emokaro C.O. (2007): Economic Importance of Cassava. In Erahbor P.O., Azaiki, S.S. and Ingawa S.A.(eds) Cassava the White Gold. Project Initiative Publication. Benin. Pp 1-22.

Ezedinma C.I., Kormawa P.M., Manyong V.M. and Dixon A.G.O.(2007): Challenges, opportunities, and strategy for cassava sub-sector development in Nigeria, In R. Kapinga, R. Kingamkono, M. Msabaha, J. Ndunguru, B. Lemaga and G. Tusiime (eds) Opportunities for Poverty Alleviation and Sustainable Livelihoods in Developing Countries. Proceedings of the Thirteenth Triennial Symposium of the International Society for Tropical Root Crops (ISTRC). Held at AICC Arusha, Tanzania, 10 - 14 November 2003, Pp $627-640$.

FAO (2002): Agricultural Marketing Extension. FAO TCP/SAF/0065, No 1 Pg1-24 http://www.nda.agric.za/docs/GenPub/1AgriMarketExtension.pdf

FAO, (1997): Marketing Improvement in the Developing World: what happens and what we have learned, In Abbott J. C. (ed), Food and agricultural marketing improvements. Rome: Italy. pp1-16.

FAO (2009): Cassava Production for countries by commodities. Food and Agricultural commodities production. www.faostat.fao.org .Date retrieved 10/01/2010

Nweke Felix Dustan S.O Spencer and John K. Lynan (2002): The Cassav Transformation African's Best-Kept Secret. Ibadan. International Institute of Tropical Agriculture (IITA). Pp 188.

Nweke, F.I., Ugwu, B.O, Dixon, A.G.O., Asadu and Ajobo, O. (1997): Cassava Production in Nigeria: A Function of Farmers Access to Market and to Improve Production and Processing Technology. COSCA working paper No. 21 COSCA, IITA Ibadan, Nigeria.

Ogundari K. and Ojo S. O. (2007): An Examination of Technical, Economic and Allocative Efficiency of Small Farms: The Case Study of Cassava Farmers in Osun State of Nigeria. Bulgarian Journal of Agricultural Science, National Centre for Agrarian Sciences. 13, 185-195.

Posavac, E.J., Carey, R.G. (1992). Program Evaluation: Methods and Case Studies. Prentice-Hall, Englewood Cliffs, NJ, Pp. 100-117. 
Singh J.P. (2001): Strategy for Affective Agricultural Marketing Extension to Meet the Challenges in 21st Century. Manage Extension Research Review. July - December, Pp 1-8.

Srivastava J.N.L (2007): Recommendations of Working Group on Agricultural Extension for Formulation of Eleventh Five-year plan (2007-12) Working Group on Agricultural Extension Constituted by Planning Commission, Govt. of India New Delhi Pg 3 Retrieved January 11, 2010 from, planningcommission.nic.in/aboutus/committee/wrkgrp11/wg11_agrext.pdf 